\title{
Endoscopicaly assisted microdebrider adenoidectomy versus conventional curettage adenoidectomy
}

\author{
Aida A Abdelmaksoud*, Alshimaa A. Gahlan, Zaky F. Aref, Usama K. Tayee \\ ENT Department, Faculty of Medicine, South Valley University, Qena, Egypt
}

\begin{abstract}
Background: Adenoidectomy by conventional method is an old procedure. Several new techniques discovered in this field as an electronic molecular resonance, suction diathermy, microdebrider, endoscopy, and laser.

Objectives: to assess advantages of endoscopic assessed microdebrider adenoidectomy over the conventional method intra and post-operative.

Patients and methods: 218 patients were scheduled for adenoidectomy were divided into two groups) underwent conventional curettage, group B (106 patients) underwent endoscopic assessed microdebrider. Follow up for 2 weeks ended by endoscopic evaluation.

Results: This study included 218 patients (110 males and 108 females) aged 2 years till 14 years, divided randomly into two groups group A 112 patients group B 106 patients. This study reported statistically longer time of operation in group B than group A (13.7 for group B \pm 3.5 versus $3.5 \pm 1.3)$. Blood loss was statistically more in group A $((26.7 \pm 7.5$ for group A versus $17.9 \pm 5.2)$. Adenoid tissues remnants in group A were statistically higher than group B (27.4\% \pm 11.6 for group A versus $1.7 \% \pm .86$ ). Regarding pain it was significantly lower in group B in the six day $(4.2 \pm 1.2$ for group A versus $2.3 \pm .5)$.

Conclusion: endoscopic assessed adenoidectomy is significantly better than conventional adenoidectomy regarding blood loss, post-operative remnantsand post-operative pain.

Key words: conventional, endoscopic,adenoidectomy, microdebrider
\end{abstract}

\section{Introduction}

Adenoidectomy is one of the most common surgical operations performed for children, combined in most cases with tonsillectomy and/or ventilation tube insertion (Hall and Lawrence 1998, Hall and Lawrence 2002, Benito et al., 2006).

Adenoidectomy by conventional method is an old procedure, first described by Wilhelm Meyer, in 1969 (Thornva,1969). Various indications for these procedures such as:obstructive sleep apnea, adenoid hypertrophy, recurrent otitis media and otitis media with effusion (Murray et al.,2002, Tarantino et al.,2004). Several new techniques discovered in this field as an electronic molecular resonance, suction diathermy, microdebrider, endoscopy, and laser (Walker,2001, Sorin et al.,2004). Each method has its own advantages and disadvantages regarding operative time,intraoperative blood loss, complications as;post-operative pain and complete removal of the adenoid tissue (Shin andHartnick,2003, Ozkiriş, 2013).

Adenoid curettage is still the most common procedures used all over the world (Van et al.,2011).

Earlier studies reported recurrence rates between $8 \%$ and $40 \%$ which dropped to $<1 \%$ in the new Techniques, but increasing expertise and cost are the major difficult why some of the newer techniques are not commonly used (Ezzat.,2010). 
Microdebrider used with endoscopes for adenoidectomy. And successful results have been reported regarding complete removal of adenoid tissue under vision, and restoration of nasopharyngeal patency (Becker,2000).

\section{Patients and methods}

This study included 218 patients (110 males and 108 females) were scheduled for adenoidectomy during the period from January 2017 to February 2019. Their ages ranged from 2 to 14 years. Inclusion criteria were; sympatomatic adenoids hypertrophy,or adenoid hypertrophy associated withchronic tonsillitis or complicated with OME. All procedures and patient care were done at the ENT Department, Qena University Hospital, and South Valley University. Patients enrolled in this study were divided into two groups. Group A (112 patients) underwent conventional curettage adenoidectomy, while Group B (106 patients) underwent endoscopically assisted microdebrider adenoidectomy.

\section{Surgical Technique:All procedures performed were carried under general anesthesia.If there is associated chronic tonsillitis or otitis media with effusion, adenoidectomy is done first followed by tonsillectomy, myringotomy and ventilation tubes application.}

The size of adenoidswas assessed using Intraoperative nasal endoscopy and graded according to Clemens and McMurray scale (Clemens et al.,1998) which is:Grade I has adenoid tissue filling 1:3 the vertical height of the choana, Grade II up to 2:3, Grade III from $2: 3$ to nearly all but not complete filling of the choana and Grade IV with complete choanal obstruction..

Group A:the patients were placed in the Rose position .Boyle-Davis mouth gag was applied; the palate was palpated to exclude a sub mucosal cleft. Using St Clair Thompson adenoid curette, adenoidectomy was done. Homeostasis was done by applying a nasopharyngeal pack. The pack was kept for few minutes and then removed.

Group B: the patient's position was as for a standard functional endoscopic sinus surgery. The posterior choanae and nasopharynx were assessed using a $0^{\circ}, 2.7$ $\mathrm{mm}$ rigid endoscope or a 4-mm scope in older children. Removal of adenoid tissue was done with microdebrider under endoscopic vision, from proximal to distal with care not to injure the torus tubarius. The tissues were removed at the site of the oscillating blade only, and the blade was kept under vision all the time using the scope. Saline irrigation was used when required. Follow up of all patients postoperative for two weeks.

\section{Assessment Parameters: Tocompare} between the conventional curettage adenoidectomy and endoscopically assisted microdebrider adenoidectomy several operative postoperative parameters were assessed.

\section{Operative Assessment Data:}

1-operative time: Intra-operative time in minutes was a assessed using stop watch, starting from application of the mouth gag till its removal or till the beginning of another procedure like tonsillectomy or myringotomy.

2-blood loss: The amount of blood included was calculated by subtracting the amount of saline used for irrigation from the total collected fluid volume.

3-Completeness of removal: Assessed by nasal endoscopy after two weeks of performing the procedure in both groups. Any adenoids remnant was recorded regarding size and site. 


\section{Postoperative Assessment Data}

1-Post-operative pain: Early post-operative pain which was measured 2 days postoperative (after exclusion of patients who underwent tonsillectomy) assessed by a visual analogue scale (VAS). A score of one means "no pain", while a score of ten is "maximal pain (Bradley and Galer, 1996).

2-Follow up: Patients were asked to come back for Follow up at 2 days, 6 days, and 2 weeks after surgery. In the first and second visit Symptomatic assessment was done, after 2 weeks endoscopic assessment was done.

Statistical Analysis: Sample size was 218 patients. A comparison between the two groups was then carried. This was done based on the operative and postoperative values previously mentioned for assessment. Data will be analyzed usingStatistical Package for Social Sciences (SPSS) software program (version 20). -Qualitative variable will be recorded as frequencies and percentages and will be compared by chisquare test.- Quantitative measure will be presented as means \pm standard deviation (SD) and will be compared by student t- test. $P$ value $<0.05$ will be significant

\section{Results}

This study included 218 patients (110 males and 108 females) there age groups ranged from 2 years till 14 years. These patients were scheduled for adenoidectomy either alone or with tonsillectomy or with myringotomy and application of ventilation tubes; according to the presentation.

For all patients $33(15.1 \%)$ patient presented with adenoid hypertrophy alone, 71patients $(32.6 \%)$ presented with adenoids with chronic tonsillitis, and 114 patients $(52.3 \%)$ presented with adenoids and otitis media with effusion (table 1).

Table: 1 Demographic data for all patients included in the study

\begin{tabular}{|l|l|l|}
\hline \multirow{4}{*}{ Group } & Conventional (group A) & $106(48.6 \%)$ \\
\cline { 2 - 3 } & Endoscopic (group B) & $112(51.4 \%)$ \\
\hline \multirow{3}{*}{ Subgroups } & Adenoids & $33(15.1 \%)$ \\
\cline { 2 - 3 } & $\begin{array}{l}\text { Adenoids+choronic } \\
\text { tonsillitis }\end{array}$ & $71(32.6 \%)$ \\
\cline { 2 - 3 } & $\begin{array}{l}\text { Adenoids +otitis media with } \\
\text { effusion }\end{array}$ & $114(52.3 \%)$ \\
\hline Age & Males & $110(50.5 \%)$ \\
\cline { 2 - 3 } & Females & $6.3 \pm 2.2$ \\
\hline
\end{tabular}

This study was age and sex matched. Group A (conventional adenoidectomy) included 112 patients 58 males and 54 females, group B included 106 patients (52 males and 54 females) with no statistical difference (table 2)
According to sex no statistical significant difference between group A and group B (table 2). 
Table: 2 Demographic data for conventional and endoscopic group

\begin{tabular}{|c|c|c|c|c|c|}
\hline Variable & \multicolumn{2}{|c|}{$\begin{array}{l}\text { Conventional } \\
\text { NO. } 112\end{array}$} & \multicolumn{2}{|c|}{$\begin{array}{l}\text { Endoscopic } \\
\text { NO. } 106\end{array}$} & $\mathrm{P}$ value \\
\hline adenoid & \multicolumn{2}{|l|}{15} & \multicolumn{2}{|l|}{18} & \\
\hline Adenoids+ ch tonsillitis & \multicolumn{2}{|l|}{35} & \multicolumn{2}{|l|}{36} & \\
\hline Adenoids+ OME & \multicolumn{2}{|l|}{62} & \multicolumn{2}{|l|}{52} & \\
\hline \multicolumn{6}{|l|}{ Age } \\
\hline Adenoids & \multicolumn{2}{|c|}{$6.9 \pm 2.2$} & \multicolumn{2}{|c|}{$6 \pm 2.3$} & .3 \\
\hline Adenoids + Tonsillitis & \multicolumn{2}{|c|}{$6.6 \pm 2.3$} & \multicolumn{2}{|c|}{$5.8 \pm 1.9$} & .5 \\
\hline Adenoids + OME & \multicolumn{2}{|c|}{$6.8 \pm 2.1$} & \multicolumn{2}{|c|}{$5.9 \pm 2.2$} & .8 \\
\hline \multirow{4}{*}{$\begin{array}{l}\text { Sex } \\
\text { Adenoids } \\
\text { Adenoids + Tonsillitis } \\
\text { Adenoids + OME }\end{array}$} & Male & Female & Male & Female & \\
\hline & 6 & 9 & 8 & 10 & .8 \\
\hline & 20 & 15 & 16 & 20 & .3 \\
\hline & 32 & 30 & 28 & 24 & .8 \\
\hline
\end{tabular}

\section{Intraoperative results}

This study reported longer time of endoscopic adenoidectomy than that of conventional method with mean \pm SD (13.7 \pm 3.5 for group B versus $3.5 \pm 1.3$ for group B) with $\mathrm{p}$ value .000 which is highly statistical significant (table 3, figure 1).

As regard blood loss conventional adenoidectomy was accompanied with much more intraoperative blood loss than endoscopic one with mean \pm SD $(26.7 \pm 7.5$ for group A versus $17.9 \pm 5.2$ ) with highly statistical $\mathrm{p}$ value (table 3 , figure 1 ).

After two weeks of performing the operations, endoscopic follow up of all patients to detect remnants of adenoid tissues reveled:more adenoid remnants in conventional method than endoscopic one. Adenoid remnants in conventional type were(27.4 \pm 11.6) for conventional method versus $1.7 \% \pm .86$ in endoscopic type with highly statistical significant difference (table 3 , figure 1).

Table 3.Comparisons between conventional adenoidectomy and endoscopic one intra and post-operative

\begin{tabular}{|l|l|l|l|}
\hline Variable & $\begin{array}{l}\text { Conventional } \\
\text { Adenoidectomy (A) }\end{array}$ & $\begin{array}{l}\text { Endoscopic } \\
\text { adenoidectomy (B) }\end{array}$ & P value \\
\hline Duration & $3.5 \pm 1.3$ & $13.7 \pm 3.5$ & $.000^{*}$ \\
\hline Blood loss & $26.7 \pm 7.5$ & $17.9 \pm 5.2$ & $.000^{*}$ \\
\hline $\begin{array}{l}\text { Post endoscopy } \\
\text { adenoid remnants }\end{array}$ & $27.4 \% \pm 11.6$ & $1.7 \% \pm .86$ & $.000^{*}$ \\
\hline
\end{tabular}

Regarding pain it was assessed after two days, it was $(6.5 \pm 1.1)$ for conventional versus $(6.5 \pm 1.1)$ for endoscopic with no statistical significant difference, on the other hand; assessment of pain after6 days reveled that pain is more sever in conventional than 
that of endoscopic type with mean \pm SD $(4.2$ \pm 1.2 for group A versus $2.3 \pm .5$ ) with highly statistical significant difference (table 4, figure 1).

Table 4: comparision between coventional adenoidectomy and endoscopic regarding pain

\begin{tabular}{|l|l|l|l|}
\hline Variable & $\begin{array}{l}\text { Conventional } \\
\text { Adenoidectomy (A) }\end{array}$ & $\begin{array}{l}\text { Endoscopic } \\
\text { adenoidectomy (B) }\end{array}$ & P value \\
\hline Pain after 2 days & $6.5 \pm 1.1$ & $6.5 \pm 1.1$ & .5 \\
\hline Pain after 6 days & $4.2 \pm 1.2$ & $2.3 \pm .5$ & $.000^{*}$ \\
\hline
\end{tabular}

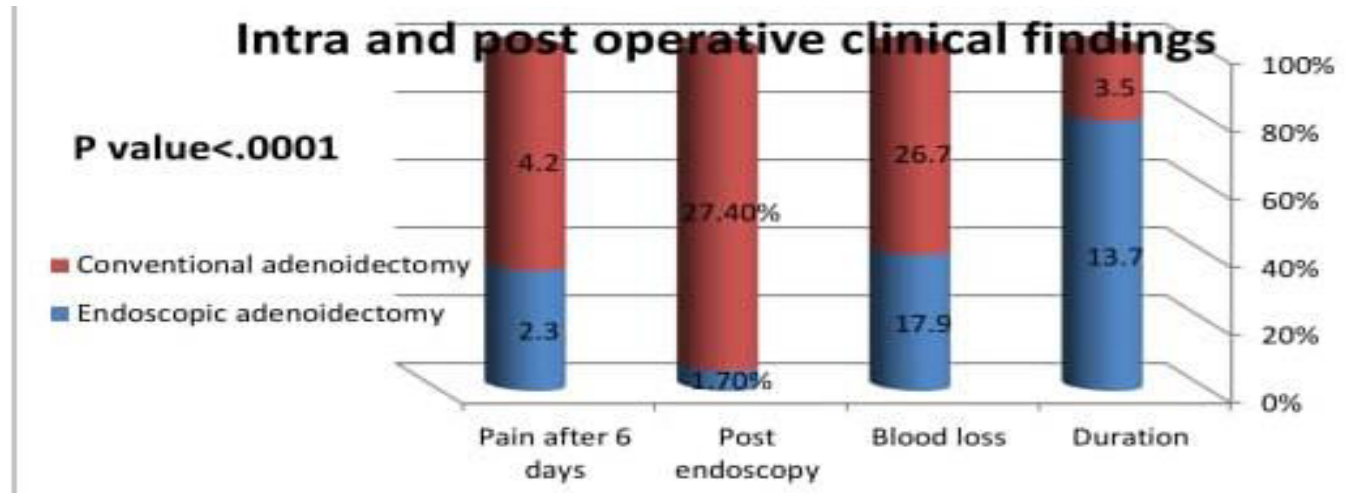

Figure 1: Comparison between intraoperative and postoperative results of both groups

\section{Discussion}

Conventional curettage may be associated with complications as it is blind technique; injury to pharyngeal musculature or eustachian tube orifice and, incomplete removal are the common complications (Cannon et al.,1999, Havas and Lowinger,2002 ), Incomplete removal may lead to peritubal obstruction, hyperplasia of adenoid tissue remnants, and site for bacterial reservoirs.Endoscopicassisted microdebrider adenoidectomy came into existence Adenoidectomy in young children should be under vision, easy performed, short operating time,with minimal blood loss, suitable cost, rapid cure of symptoms and complete adenoid resection without complications.

This study reported longer duration of operation in endoscopic than conventional adenoidectomy this is in agreement with Singh et al who reported that time of conventional operation and its blood loss is three times more than endoscopic one (Singh et al.,2019) but five studies reported operative time in meta-analysis showed that endoscopic assisted adenoidectomy was shorter time than conventional one (Bradoo et al.,2016).

As regard blood loss this study showed more blood loss in conventional procedure than endoscopic one this is in agreement with Singh et al (Singh et al.,2019). Other studies 
done by Heras and Koltai 1998, Koltai et al.,2002, Rodriguez et al., 2002, and Murray et al., 2002 who reported less total blood loss and operative time in endoscopic-assisted technique. Bradoo et al.,2016 showed that intraoperative blood loss is the same in both methods.

Results of this study showed more adenoid remnants in conventional method(27.4\% \pm 11.6) than endoscopic one, similar to results done by Stanislaw et al., 2000,Havas and Lowinger,2002,Datta al,.2009,Ezzat,2010, Hussein and AlJuboori,2012, with an incidence of $39 \%, 39 \%$, 30\%, $14.5 \%$, and $20 \%$, respectively.

\section{References}

Al-Mazrou KA, Al-Qahtani A, Al-Fayez AI.(2009). Effectiveness of transnasal endoscopic powered adenoidectomy in patients with choanal adenoids.Int $\mathbf{J}$ PediatrOtorhinolaryngol, 73(12):1650-1652.

Becker DG.(2000). Powered instrumentation in surgery of the nose and paranasal sinuses.Otolaryngol Head Neck Surg, 8(1):18-21.

Benito Orejas JI, Alonso Mesonero M, Almaraz Gomez A, Morais Perez D, Santos Perez J. (2006). Trend changes in the adenotonsillar surgery. Otorhinolaryngollbero Am, 33(6):573-58.

Bradley S. Galer MD. Pain management: Theory and practice: Contemporary neurology series, vol 48 Russell K. Portenoy and Ronald M. Kanner, Philadelphia, FA Davis, 1996: J Annals of neurology, 357 pp, https://doi.org/10.1002/ana.410400530.

Bradoo AR, Modi RR, Joshi AA, Wahane A. (2016).Comparison of EndoscopicAssisted Adenoidectomy with Conventional Method, jp-journals, 10013-1077.

Cannon CR, Replogle WH, Schenk MP.(1999). Endoscopic assisted
Al-Mazrou et al., 2009,Regmi et al., 2011,Viorel, 2011, and Capaccio et al., 2016reported missed adenoid tissue in conventional curettage.

Pain score after two days of the operation in both groups showed no statistical significant difference but in the six day there was significant decrease in pain score in endoscopic group than conventional one similar to resulrs reported by Datta et al.,2009,Somani et al.,2010.

Conclusion endoscopic assessed adenoidectomy has several advantages than conventional type, it has less blood loss, less post-operative remnants, less post-operative pain, and it is the best choice for children

adenoidectomy. Otolaryngol Head Neck Surg., 121(6): 740-4.

Capaccio P, Torretta S, Marciante GA. (2016). Endoscopic adenoidectomy in children with otitis media with effusion and mild hearing loss. ClinExpOtorhinolaryngol, 9:33.

Clemens J, McMurray JS, Willging JP.(1998). Electrocautery versus curette adenoidectomy: comparison of postoperative results. International journal of pediatric otorhinolaryngology, 43(2):11522.

Datta R, Singh VP.(2009).Deshpal. Conventional versus Endoscopic Powered Adenoidectomy: a Comparative Study. Med J. Armed Forces India, 65: 308-12.

Ezzat WF.(2010).Role of endoscopic nasal examination in reduction of nasopharyngeal adenoid recurrence rates.Int. J.PediatrOtorhinolaryngol, 74(4): 404-6.

Hall MJ, Lawrence L. (1998). Ambulatory surgery in the United States, 1996. Adv Data Vital Health Stat, 300:1-16

Hall MJ, Lawrence L. (2006). Ambulatory surgery in the United States, 1996. Adv Data Vital Health Stat, 33(6):573-581

Havas T, Lowinger D.(2002). Obstructive adenoid tissue: an indication for powered- 
shaver adenoidectomy. Arch Otolaryngol Head Neck Surg., 128(7): 789-91.

Heras HA, Koltai PJ.(1998).Safety of powered instrumentation for adenoidectomy. Int J.PediatrOtorhinolaryngol, 44(2): 14953.

Hussein IA, Al-Juboori S.(2012).Conventional versus endoscopicassisted adenoidectomy: a comparative study. Med J. Babylon, 9(3): 570-82.

Koltai PJ, Chan J, Younes A.(2002).Power-assisted adenoidectomy: total and partial resection. Laryngoscope, 112(8 Pt 2 Suppl 100): 29-31.

Murray N, Fitzpatrick P, Guarisco JL.(2002).Powered partial adenoidectomy.Arch Otolaryngol Head Neck Surg, 128(7):792-96.

Murray N, Fitzpatrick P, Guarisco JL.(2002).Powered partial adenoidectomy. Arch Otolaryngol Head Neck Surg., 128(7): 792-6.

Ozkiriş M, Karacavuş S, Kapusuz Z, Saydam L.(2013).Comparison of two different adenoidectomy techniques with special emphasize on postoperative nasal mucociliary clearance rates: coblation technique vs. cold curettage. Int J.PediatrOtorhinolaryngol., 77(3): 389-93.

Regmi D, Mathur NN, Bhattarai $M$. (2011). Rigid endoscopic evaluation of conventional curettage adenoidectomy. J LaryngolOtol, 125(1):53-58

Rodriguez K, Murray N, Guarisco JL.(2002). Powerassisted partial adenoidectomy. Laryngoscope, 112(8 Pt 2 Suppl 100): 26-8.

Shin JJ, Hartnick CJ.(2003).Pediatric endoscopic transnasal adenoid ablation. Ann OtolRhinolLaryngol., 112(6): 511-4.

Singh B S. Padiyar V Sharma N.(2019).Endoscopic-Assisted Powered Adenoidectomy versus Conventional Adenoidectomy: A Randomized Study, Dubai Med J., 2:41-45.
Somani SS, Naik CS, Bangad SV.(2010).Endoscopic Adenoidectomy with Microdebrider. Indian Journal of Otolaryngology and Head \& Neck Surgery,62(4):427-31.

Sorin A, Bent JP, April MM, Ward RF.(2004).Complications of microdebriderassisted powered intracapsular tonsillectomy and adenoidectomy. Laryngoscope, 114(2): 297- 300.

Stanislaw P Jr, Koltai PJ, Feustel PJ.(2000).Comparison of power-assisted adenoidectomy vs. adenoid curette adenoidectomy. Arch Otolaryngol Head Neck Surg., 126(7): 845-9.

Tarantino V, D'Agostino R, Melagrana A, Porcu A, Stura M, Vallarino R, et al.(2004).Safety of electronic molecular resonance adenoidectomy. Int J.PediatrOtorhinolaryngol, 68(12): 1519-23. Thornval A.(1969).Wilhelm Meyer and the adenoids. Arch Otolaryngol, 90(3): 383-6.

Van Den Akker EH, Hoes AW, Burton MJ, Schilder AGM.(2004). Large international differences in (adeno)tonsillectomy rates. Clinical Otolaryngology and Allied Sciences, 29(2):161-64.

Viorel Z. (2011).Conventional curettage adenoidectomy versus endoscopic assisted adenoidectomy. J Clin Med, 6(4):328-329

Walker P.(2001).Pediatric adenoidectomy under vision using suction-diathermy ablation. Laryngoscope, 111(12): 2173-7. 